\title{
Colorectal Cancer Screening: What Are My Options?
}

\author{
Osama Abbas Orabi \\ (Internal Medicine Department Sohag University Hospital)
}

\section{INTRODUCTION}

Colorectal cancer (CRC) is the third most prevalent cancer both worldwide (1.23 million annual cases) and in the United States $(132,700$ annual cases). ${ }^{1,2}$ While CRC mortality in the United States has been falling since 1985, attributed to both uptake of screening and advancements in treatment, an estimated 49,700 die annually, $\underline{3}$ suggesting the need for continued screening efforts. The basis of CRC screening dates to the discovery of precancerous adenomatous tissue, ${ }^{4}$ which led to the understanding of development of CRC through the "adenoma-carcinoma" sequence rather than directly arising from the colorectal mucosa.,$\underline{5}$ Screening allows for early detection of $\mathrm{CRC}$ and removal of precancerous lesions, leading to reductions in cancer incidence and mortality.

No one looks forward to a bowel prep that goes with some colorectal cancer screening tests. But colorectal cancer screening - testing to look for cancer before symptoms start - can help save lives. Screening can find colorectal cancer early when it's small and might be easier to treat. There are several different screening options available. No matter which one you choose, the important thing is to be tested.

The recommended tests fall into 2 categories:

(Stool-based tests)

Stool-based tests are non-invasive colorectal cancer screening options. No special diet or bowel preparation (no laxatives or enemas) is required for a stool-based test. However, if the test does show abnormal signs of blood or a possible cancer or pre-cancer, a colonoscopy will be needed to confirm the result, and possibly to remove any abnormal findings or polyps. It's important to remember the cause of an abnormal result may be a noncancerous condition, such as ulcers or hemorrhoids.

Stool-based tests are not the best option for everyone. They are recommended for people who have an average risk for colorectal cancer: no personal history of pre-cancerous polyps, no colorectal cancer that runs in the family, or no other risk factors.

- Fecal immunochemical test (FIT) and guaiac-based fecal occult blood test (gFOBT) are non-invasive tests used to find tiny amounts of blood in the stool that could be a sign of cancer or large polyps. People take these tests at home with a kit they receive from their doctor's office, along with instructions on how to do the test and return it so it can be checked. Each test detects blood differently, but neither test can tell where the blood might be coming from. That's why any abnormal result will need to be followed up with a colonoscopy. Stool tests like these need to be done every year.

- Stool DNA testing is another type of non-invasive test to check for colorectal cancer. It looks for certain DNA or gene changes that often get into the stool and are sometimes found in pre-cancerous growths and cancer cells. It also checks for blood in the stool, which can be a sign of cancer. If a stool DNA test finds something abnormal, a colonoscopy will be needed to follow-up on the findings. For this test, people use a take-home kit to collect a stool 
sample and mail it to a lab. Cologuard ${ }^{\circledR}$ is the name of the stool DNA test that is currently FDAapproved, and the patient gets it from their doctor's office.

\section{(Visual tests)}

Visual or structural tests are invasive tests that look inside the colon and rectum for abnormal areas that might be cancer or polyps. If a stool-based test was done first and had an abnormal result, a visual test can help find out why.

- Colonoscopy uses a flexible lighted tube with a small camera on the end to look at the entire length of the colon and rectum. If polyps are found, they may be removed during the test. To prepare for the test, you may be asked to follow a special diet for a day or two before the test. You will also need to clean out your colon with strong laxatives (called a bowel prep) and sometimes with enemas, as well. Most people are sedated during the test. If nothing is found during the test, you won't need another one for 10 years.

- CT colonography (also called virtual colonoscopy) is a scan of the colon and rectum that produces detailed cross-sectional images so the doctor can look for polyps or cancer. It

- requires bowel prep, but no sedation. Air is pumped into the rectum and colon, and then a CT scanner is used to take images of the colon. If something is seen that may need to be biopsied, a follow-up colonoscopy will be needed. CT colonography must be done every 5 years.

- Flexible sigmoidoscopy is not widely used for colorectal cancer screening in the U.S. It's like a colonoscopy, but only looks at a certain part of the colon and rectum instead of looking at the entire length of the colon and rectum. If polyps are found, they may be removed during the test, or you may need to have a colonoscopy later. Bowel prep may be required, but is not as extensive as the one used for colonoscopy. Most people do not need to be sedated during this test. If polyps or suspicious areas are seen, a colonoscopy will be needed to look at the rest of the colon. Flexible sigmoidoscopy must be done every 5 years.

Talk to your doctor about screening Regular screening is one of the most powerful ways to prevent colorectal cancer. If polyps are found during colorectal cancer testing, they can usually be removed before they have the chance to turn into cancer. Testing can also result in finding cancer early, when it's smaller and might be easier to treat.

If you're 45 or older, talk to your doctor about which screening test is right for you, and talk to your insurance company about coverage. It's important to get tested as often as recommended. No matter what your age, talk to your doctor about your family medical history. People at higher risk for colorectal cancer because of family history or certain health conditions might need to start screening earlier than age 45 .

\section{CONCLUSIONS}

The past 15 years have seen improvement in the uptake of CRC screening and reduction in $\mathrm{CRC}$ incidence and mortality in the United States. While colonoscopy is currently the dominant screening test in the United States, there is considerable interest in the development of accurate noninvasive screening tests, with notable improvements in stool-based tests in particular. Both FIT and sDNA provide viable noninvasive options to colonoscopy for average-risk persons. Both tests provide several advantages over colonoscopy, including ease of completion, low cost, and low risk. 
Ongoing research of sDNA will quantify its uptake, adherence, costeffectiveness, and appropriateness of the 3-year testing interval. FIT and sDNA, should be included as options in discussions of CRC screening between provider and patient, with expectation of improved adherence to screening. Continued development of noninvasive tests, improved understanding of optimal screening intervals, and greater ability to risk stratify are likely to improve the efficiency of and adherence to CRC screening.

\section{REFERENCES}

1. Ferlay J, Shin HR, Bray F, Forman D, Mathers C, Parkin DM. Estimates of worldwide burden of cancer in 2008: GLOBOCAN 2008. Int J Cancer. 2010;127:2893-2917. doi: 10.1002/ijc.25516. [PubMed] [CrossRef]

2. Siegel RL, Miller KD, Jemal A. Cancer statistics, 2015. CA Cancer J Clin. 2015;65:5-29. doi: 10.3322/caac.21254.

[PubMed] [CrossRef]

3. Edwards BK, Noone AM, Mariotto $\mathrm{AB}$, et al. Annual Report to the Nation on the status of cancer, 1975-2010, featuring prevalence of comorbidity and impact on survival among persons with lung, colorectal, breast, or prostate cancer. Cancer. 2014;120:1290-1314. doi: $10.1002 / \mathrm{cncr} .28509$. [PMC free article] [PubMed] [CrossRef]

4. Lockhart-Mummery JP, Dukes C. The precancerous changes in the rectum and colon. SurgGynecol Obstet. 1928;36:591-596.

5. Fearon ER, Vogelstein B. A genetic model for colorectal tumorigenesis. Cell. 1990;61:759-767. doi: 10.1016/0092-8674(90)90186-I. [PubMed] [CrossRef]

6. Winawer SJ, Zauber AG, Ho MN, et al. Prevention of colorectal cancer by colonoscopicpolypectomy. The National Polyp Study Workgroup. N Engl J Med. 1993;329:1977-1981. doi:
10.1056/NEJM199312303292701. [PubMed] [CrossRef]

7. Brenner H, Chang-Claude J, Seiler CM, Rickert A, Hoffmeister M. Protection from colorectal cancer after colonoscopy: a population-based, casecontrol study. Ann Intern Med. 2011;154:22-30. doi: 10.7326/00034819-154-1-201101040-00004.

[PubMed] [CrossRef]

8. DeSantis CE, Lin CC, Mariotto AB, et al. Cancer treatment and survivorship statistics, 2014. CA Cancer J Clin. 2014;64:252-271. doi: 10.3322/caac.21235. [PubMed] [CrossRef]

9. Schreuders EH, Ruco A, Rabeneck L, et al. Colorectal cancer screening: a global overview of existing programmes. Gut. 2015;64:1637-1649. doi: $\quad$ 10.1136/gutjnl-2014-309086. [PubMed] [CrossRef]

10.Centers for Disease Control and Prevention (CDC) Vital signs: colorectal cancer screening test use: United States, 2012. MMWR Morb Mortal Wkly Rep. 2013;62:881-888. [PMC free article] [PubMed]

11. Gupta S, Sussman DA, Doubeni CA, et al. Challenges and possible solutions to colorectal cancer screening for the underserved. J Natl Cancer Inst. 2014;106:dju032. doi: 10.1093/jnci/dju032. [PMC free article] [PubMed] [CrossRef]

12. Rex DK, Johnson DA, Anderson JC, et al. American College of Gastroenterology guidelines for colorectal cancer screening 2009 [corrected] Am J Gastroenterol. 2009;104:739-750. doi: 10.1038/ajg.2009.104. [PubMed] [CrossRef]

13. Burt RW, Cannon JA, David DS, et al. Colorectal cancer screening. J NatlComprCancNetw. 2013;11:15381575. [PubMed]

14.U.S. Preventive Services Task Force. Screening for colorectal cancer: U.S. Preventive Services Task Force recommendation statement. Ann Intern Med. 2008;149:627-637. doi: 10.7326/0003-4819-149-9-20081104000243. [PubMed] [CrossRef] 
SOHAG MEDICAL JOURNAL

Vol. 23 No.1 Jan 2019
Colorectal Cancer Screening: What Are My Options? Osama Abbas Orabi

15.Levin B, Lieberman DA, McFarland B, et al. Screening and surveillance for the early detection of colorectal cancer and adenomatous polyps, 2008: a joint guideline from the American Cancer Society, the 